\title{
Research and Design on Passengers Traffic Information Services Mode of Hongqiao Transport Hub
}

\author{
Honglin Xiong (Corresponding author) \\ Business School, University of Shanghai for Science and Technology \\ Shanghai 200093, China \\ E-mail: dianyi0467@yahoo.com.cn \\ Chongjun Fan \\ Business School, University of Shanghai for Science and Technology \\ Shanghai 200093, China \\ E-mail: cjfan@sh163.net \\ Xiaodong Zhu \\ Business School, University of Shanghai for Science and Technology \\ Shanghai 200093, China \\ Wenchun Shu \\ Shanghai Airport Construction Headquarters \\ Shanghai 201202, China \\ Zhuojian Zhang \\ Shanghai Airport Construction Headquarters \\ Shanghai 201202, China \\ Qingzheng Ji \\ Easyway Science Stock Llimited Liability Company \\ Beijing 100083, China
}

The research is financed by the research project of Science and Technology Commission of Shanghai Municipality of China. No. 062112051 (Sponsoring information)

The research was supported by Shanghai Development of Undergraduate Education Base III_Electronic Commerce

\begin{abstract}
This paper firstly have analyzed how do Hongqiao Transport Hub provide passengers with humanized information service. Then, combined with the space structure and the modes of transportation, from the point of view of information published location, this paper discusses Hongqiao Transport Hub's information services, information dissemination channels and information forms based on location.
\end{abstract}

Keywords: Hongqiao transport hub, Multiple Modes of Transportation Transfer, Passenger information services, Electronic commerce

\section{Introduction}

Based on Hongqiao Airport, Hongqiao transport hub gradually formed a multi-transport hub. When Shanghai Hongqiao comprehensive transport Hub project is completed, it sets railway, Pudong Maglev and Huhang Maglev, airport, bus, subway, long-distance bus terminal and taxi in one. In other words, Hongqiao transport hub 
will be a centre for all modes of transportation.

As Shanghai Hongqiao transport hub changes into a variety of modes of transport hub, the traffic is more heavy than before, the organization and management of passenger flow has increased sharply, how to use the advantages of information technology to cope with the organization and scheduling of passengers under the new situation is extremely necessary. Firstly, the potential passenger information services demand from passengers' psychology and behaviors angles. Secondly, this paper analyses the information need to be collected and obtained and the channels and forms in which the information is displayed in front of passengers in order to meet the needs of these information services. Finally, sums up the information service structure of Hongqiao Hub and lay emphasis on building human-oriented transportation hub is a inevitable trend to build modern transport hub.

\section{Analysis on Passenger Oriented Information Services Constitute}

Passengers travel for Hongqiao Ttransport Hub includes the two basic steps:

Step 1 is how to access to information;

Step 2 is how to transport passengers.

With the development of society, modes of transportation are more and more diversified and travel destinations and modes for tourists are becoming increasingly diversity. At the same time, as world Expo is approaching, Hongqiao Transport Hub will face enormous pressure to deal with the heavy traffics; also passengers will increase the requirements and quality of oriented information simultaneously. In order to display the passengers' information needs completely, analyze of demand state and evolution, this paper analyze the passenger information needs hierarchy and the composition of passengers.

\subsection{Analysis of Needs Hierarchy Based on Passenger Information}

Maslow's theory stands a psychological point of view, said like this: a person's social need, from the survival needs to security needs, then to social needs and up to respect needs, until the self-realization. Through Maslow's hierarchy of needs theory we can build a demand model of information demand situation for passengers. Table 1 shows the information needs for passengers corresponding to a variety of modes of transportation.

$<$ Insert table 1 here $>$

Passengers choose to travel by a certain means of transport means that the basic conditions for travel is satisfied, this case is located in the first hierarchy corresponds to Maslow's theory. At this hierarchy, start or take off time, delay notice, the first and last time of train or bus, etc, all of them are main information needs. At the same time, as the hub is located outside Shanghai's prosperous commercial circles, how to let passengers reach hub is quite significant.

Passengers' security needs more emphasis on getting destination with a sense of security during trips. The passengers need to know their current location, routes, times, channels, etc, city traffic integrated transfer information play an important role for them. This hierarchy will allow tourists to get help faster, optimize the travel experience for visitors.

Basic operational information needs and guided information needs make up the primary stage of passenger information needs is also a rigid demand.

Stage of personalized information needs builds on rigid needs. It including trip target information needs, private space needs and service role in the change process, these are correspond to Maslow's model of social needs, respect needs and self-fulfilling hierarchy.

Trip target information needs have fulfilled the diversity of leisure and social intercourse during the trip, by this way, it can meet the visitors' individual needs in the tourism and travel during the sightseeing, shopping, leisure or in business activities.

Private space needs will make full use of passenger waiting time at the hub, under this case, it has meet the spiritual needs purpose of passengers. In order to enrich the visitor experience at the hub during the waiting time, especially in the airport or High Spread Rail, by create personal spiritual space to achieve "more economical", "richer", and "more exciting" trip experience.

In the last hierarchy, passengers themselves access to services, at the same time, enriched the services. This process is similar to the Internet, SNS community-based service experiences. In this hierarchy, the needs of tourists showed more personality and varied trend, this is the result that the ever-changing demands and enhance of the user experience, and it is worthy keeping attention.

From the above analysis we can see that passengers' information services have a natural process of growing and 
needs.

\subsection{Analysis of the Composition of Passengers Based on Hongqiao Transport Hub}

The passengers of Hongqiao Transport Hub can be divided into the following four categories: (1)The passengers who start from Hongqiao Transport Hub to some place by train or air; (2)The passengers who arrive in Hongqiao Transport Hub far way from Shanghai and want to reach downtown area; (3)The passengers who stay at Hongqiao Transport Hub for a moment and leave here to same place; (4)The passengers who get Hongqiao Transport Hub to pick friends and relatives or to see them off.

According to the different needs of travelers and provide different information services. For example, through the website or else ways, passengers can obtain relevant information before he or she has get hub, it help passengers get themselves needs information.

\subsubsection{Information Services for Passengers pre-trip or before Get Hongqiao Hub}

Before passengers have arrived at Hongqiao Hub, they can access Internet by wired or wireless to find their query requirements of relevant information, also they can choice a way to send short messages queries.

\subsubsection{Information Services for pick-up}

When the passengers will reach the hub to pick-up someone, he or she can query some information about road conditions, parking spaces, road traffic, parking status, flight, etc, by Intelligent Query Web site.

\subsubsection{Information services for passenger get Hongqiao Hub}

When passengers get the hub, he or she can meet his or her different information needs by three modes, which are the self-check terminal mode, direct view mode, as well as wireless network queries mode.

\subsubsection{For the passengers who is leaving the Hub}

Passengers who is leaving the hub, he or she can inquire some information such as passenger density, his or her own position present, routes and so on, then he or his chose the most appropriate way to leave the hub.

When public area of the hub or a certain mode of transport has an accident, passenger traffic operations center can guide visitors to divert by display system release evacuated formation, to minimize the adverse impact of the accident.

\subsubsection{For the Passengers who have arrived in the Hub}

\section{Implementation Steps of Information Service}

Building information services in Hongqiao Hub is not an overnight thing, but requires us to confront the objective environment with initiative and open mind and make adjustments adaptively. The change and improvement of the information service can not only reflect information' technology, the latest development on transmitting and sharing technology, but also meet to the passage's consistently changing living environment and mentality. The most reasonable way to constructing the current hub information services is to set personalized information services as target, make continued deployment information service in different stage and different levels so that transport hub and passages can coexist harmony. According to the analysis of information demand from passengers, the relationship between main and ancillary information and the implement phase are as followed in the Table 2.

$<$ Insert table 2 here $>$

\section{Information Services Show}

\subsection{Information Carrier}

Information carrier can be divided into three types, they are interactive query facilities, dynamic information display facilities, and mobile information facilities, as shown in Table 3.

$<$ Insert table 3 here $>$

\subsection{Analysis of Carrier Location}

To give full play to the role of information facilities, the premise is to correct location facilities, this is not a simple construction problems. Carrier lactation would have to follow certain principles.

Facilities and the principles of choose position are summarized as follows: the demand-driven focus and details are connected with the location; navigation program based on best path to show differentiation; aim at hub environment; information in different locations have different emphasis and priority. 


\subsection{The rule of Carrier Location}

Based on the above information service demand and position analysis of information carrier, we can get four carrier rules of the deployment: Facilities must be placed in the area with high occurrence of passenger information needs or the area close to effective range of the area within high occurrence demand; facilities must be placed in position where passenger's eye-catching, in order that two-way passengers are able to see the device, it is necessary to occupy a higher visual height; Facilities must be placed in the area that the passenger can operate at any time; settings to display combined to form a self-service island, after understand the basic information on information-screen, visitors can conveniently use the query machines according to their specific needs for further inquiries.

(1)High occurrence area of passenger information needs. Means from the passengers leave the vehicle, moving in the hub, the area with spontaneous, clear strong and concentrated orientation demand and operational information needs.

(2) Operational accessibility. Accessibility means support that vulnerable groups' operation and there is no visual impairment around the peripheral equipment. In the normal operation state of Transportation Center, maximize the equipment's anti-jamming capability in an abnormal situation, improve the environment safety and comfort when passenger use the equipment.

\section{Conclusion}

Focusing on Hongqiao Hub, this paper describes the passengers' information service needs, carrier and means of transmitting information and so on. It provides the information service with phased construction classification and recommends a phased-constructional continuous integration approach for information service system construction. Additionally, this paper presenters a variety of facilities related to information release, in accordance with the fact "the demand of information from the passages in different spatial and public transport environment are diverse" it gives objective and factual description of the location of information, thereby presenting the deployment principle of constructing information server system, demonstrating a meaningful practical value.

\section{Acknowledgements}

This research was supported by the research project of Science and Technology Commission of Shanghai Municipality of China (No. 062112051), and Shanghai development of Undergraduate Education Base IIIElectronic Commerce. Express the thanks.

\section{References}

Chongjun Fan, Honglin Xiong, Haiying Zhang \& Wujun Liu. (2009). Analysis of Network Security and Risks Prevention Strategies of Hongqiao Airport West Terminal. Computer and Information Science, 2(3): 46-52.

Fan Chong-jun. (2004). Information technology strategic planning under the group management model. Construction Machinery, 35(9): 34-37.

Gu chengdong \& Liu wujun. (2007). Management and planning of transport hub construction of Shanghai Hongqiao. Comprehensive Transportation, (9): 54-57.

Kelemen, Zsolt. (2005). Resource management system - The first step to the airport information system integration, Periodica Polytechnica Transportation Engineering, 33(1): 15-24.

Lin Nong. (2003). Design and research of the airport synthetic integrated information system. Computer Engineering and Applications, 39(11): 228-229.

Wang Hai-dong. (2007). Discuss of "two airports in the same city" operation mode in Shanghai air hub. Science and Technology Information, (13): 177.

Wu Nian-zu. (2008). Construction of Pudong international airport operation information system. Shanghai: Shanghai Science and Technology Publishing House.

Zhao Hai-bo \& Liu Wu-jun. (2007). Development of Hongqiao integrated transportation hub planning. Research of Urban Rail Transport, (11): 8-9. 
Table 1. Maslow's Hierarchy of Needs Model Analysis Table

\begin{tabular}{|c|c|c|c|}
\hline Maslow Model & Hierarchy Needs of Passengers & Service & Stages \\
\hline Survival Needs & $\begin{array}{l}\text { Basic operational information } \\
\text { needs: to play a direct role in } \\
\text { judging passengers' travel plans } \\
\text { information. }\end{array}$ & $\begin{array}{l}\text { Shanghai Map; Operations } \\
\text { timetable; Stop broadcast. }\end{array}$ & \multirow[t]{2}{*}{ Rigid Needs } \\
\hline Security Needs & $\begin{array}{l}\text { Guided information needs: play the } \\
\text { role of reference to the trip for } \\
\text { passengers; bring a sense of security } \\
\text { to passengers. }\end{array}$ & $\begin{array}{l}\text { Hub guide; Traffic guide; } \\
\text { surrounding guide; City } \\
\text { comprehensive traffic } \\
\text { information ;Bus } \\
\text { integration queries }\end{array}$ & \\
\hline Social Needs & $\begin{array}{l}\text { Travel destination information } \\
\text { needs: Optimization of travel } \\
\text { experience for passenger travel } \\
\text { destination; Rich in convenience } \\
\text { and business information based on } \\
\text { hub and city traffic }\end{array}$ & $\begin{array}{l}\text { Travel information; } \\
\text { Shanghai commercial } \\
\text { streets information; } \\
\text { Recreation information; } \\
\text { Travel offers service } \\
\text { information. }\end{array}$ & \multirow{3}{*}{$\begin{array}{l}\text { Individual } \\
\text { Needs } \\
\\
\text { Individual } \\
\text { Needs }\end{array}$} \\
\hline Respect Needs & $\begin{array}{l}\text { Private space needs: A sense of } \\
\text { space is reflected in the use of } \\
\text { waiting time in the range of spiritual } \\
\text { and personal space, mainly shown } \\
\text { in private information read and } \\
\text { some small-scale personalized } \\
\text { experience }\end{array}$ & $\begin{array}{l}\text { Electronic reading; } \\
\text { Recreation projects; } \\
\text { Member service, etc. }\end{array}$ & \\
\hline $\begin{array}{l}\text { Self-actualizatio } \\
\text { n Needs }\end{array}$ & $\begin{array}{l}\text { The role of passengers transforms } \\
\text { from passive recipients of services } \\
\text { to the information producers and } \\
\text { information delivery. }\end{array}$ & $\begin{array}{c}\text { Passenger community } \\
\text { based on Hongqiao Hub; } \\
\text { More service, etc. }\end{array}$ & \\
\hline
\end{tabular}

Table 2. Implementation steps of Information Service

\begin{tabular}{|c|c|c|}
\hline phase & Main information & Ancillary information \\
\hline $\begin{array}{c}\text { Basic } \\
\text { information } \\
\text { phase }\end{array}$ & $\begin{array}{l}\text { Operating schedule; stop broadcast; } \\
\text { Shanghai maps; hub-orientations; Traffic } \\
\text { guide; Surrounding } \\
\text { neighborhood-orientation; city's } \\
\text { comprehensive traffic information; } \\
\text { integrated public transport queries }\end{array}$ & $\begin{array}{c}\text { Date; Time; temperature; meteorology; } \\
\text { instant information; electronic } \\
\text { reading }\end{array}$ \\
\hline $\begin{array}{l}\text { Special server } \\
\text { phase }\end{array}$ & $\begin{array}{l}\text { Shanghai Travel Information; Shanghai } \\
\text { commercial district information; urban } \\
\text { leisure information; Travel Offers service } \\
\text { information; Electronic reading. }\end{array}$ & $\begin{array}{l}\text { The information about Shanghai } \\
\text { Tourism Festival and other events } \\
\text { information; Expo information; } \\
\text { Theme; the information. from Yangtze } \\
\text { River Delta }\end{array}$ \\
\hline Advanced phase & $\begin{array}{l}\text { Member services; community-based hub } \\
\text { for travelers. }\end{array}$ & \\
\hline
\end{tabular}


Table 3. Information Carrier

\begin{tabular}{|c|c|c|c|c|}
\hline Carrier & Main services & Install Location & Service Platform & Principal clients \\
\hline $\begin{array}{l}\text { Interactive } \\
\text { query } \\
\text { facilities }\end{array}$ & $\begin{array}{l}\text { Provide integration of } \\
\text { transport inquiry } \\
\text { function }\end{array}$ & $\begin{array}{l}\text { To reach the major } \\
\text { regional of hub; Both } \\
\text { ends of Transfer } \\
\text { channels }\end{array}$ & $\begin{array}{l}\text { Vertical touch query } \\
\text { device }\end{array}$ & $\begin{array}{c}\text { The passengers who } \\
\text { have arrived in } \\
\text { Shanghai }\end{array}$ \\
\hline $\begin{array}{l}\text { Dynamic } \\
\text { information } \\
\text { display } \\
\text { facilities }\end{array}$ & $\begin{array}{l}\text { Provide quickly } \\
\text { browsing information, } \\
\text { instant messaging, and } \\
\text { operating conditions }\end{array}$ & $\begin{array}{l}\text { Main entrance for } \\
\text { hub; both ends of } \\
\text { Transfer channels; } \\
\text { Waiting area }\end{array}$ & $\begin{array}{c}\text { Wall-mounted } \\
\text { large-scale display } \\
\text { device }\end{array}$ & $\begin{array}{c}\text { The passengers who } \\
\text { will get or leave the } \\
\text { hub }\end{array}$ \\
\hline $\begin{array}{l}\text { Mobile } \\
\text { information } \\
\text { facilities }\end{array}$ & $\begin{array}{l}\text { Provide integrated } \\
\text { query capabilities }\end{array}$ & $\begin{array}{l}\text { Portable for } \\
\text { passengers }\end{array}$ & Mobile Software & $\begin{array}{c}\text { The passengers who } \\
\text { will get or leave the } \\
\text { hub }\end{array}$ \\
\hline
\end{tabular}

